\title{
FACTORS THAT INFLUENCE THE LEVEL OF PROFITABILITY MANAGERIAL IN MEDAN
}

\author{
Seniwati Sembiring ${ }^{1}$, Syafrida Damanik ${ }^{*}{ }^{\star}$, M. Umar Maya Putra ${ }^{1}$, Maliyah ${ }^{1}$ \\ ${ }^{1}$ Economic Faculty, Universitas Al-Azhar, Indonesia \\ ${ }^{*}$ Engineering Faculty, Universitas Al-Azhar, Indonesia
}

DOI: https://doi.org/10.29121/granthaalayah.v8.i9.2020.1413

Article Type: Research Article

Article Citation: Seniwati

Sembiring, Syafrida Damanik, M. Umar Maya Putra, and Maliyah. (2020). FACTORS THAT INFLUENCE THE LEVEL OF PROFITABILITY MANAGERIAL IN MEDAN. International Journal of Research GRANTHAALAYAH, 8(9), 209-214. https://doi.org/10.29121/granthaa layah.v8.i9.2020.1413

Received Date: 15 September 2020

Accepted Date: 30 September 2020

Keywords:

Managerial

Assert

Profitability

Medan

\section{ABSTRACT}

The purpose of this study was to determine the effect of the Current Ratio (CR), Debt to Equity Ratio (DER) and Total Assert Turn Over (TATO) on profitability Managerial in Return on Assert (ROA) for the period 20082017. The sample of financial statements that were studied for 10 years at PT. Ira Widya Utama as one of the biggest company In Medan. The data used is secondary data. This study analyzes the relationship among them. The statistical method used is multiple linear regression using the classic assumption test first. It indicates that partially the CR has a negative significant effect, DER has a positive and insignificant effect, TATO has a positive and significant effect on ROA. simultaneously, CR, DER and TATO have a positive and significant on ROA.

\section{INTRODUCTION}

The company is one form of organization that generally has a specific purpose to be achieved in its business is to meet the interests of the stakeholders. In addition the company's goals include increasing the value of the company, satisfying the needs of the community and to obtain profits . The company's performance will determine the achievement of these objectives and will be the basis for returning decisions for internal and external parties.

ROA makes the extent to which investments that have been invested are able to provide returns as expected and the investment is actually the same as the company's assets that are invested or placed. It is one indicator to measure a company's financial performance and is a profitability ratio that is used to measure the effectiveness of a company in generating profits by utilizing the total assets it has. ROA is the ratio between Net Income After Tax (NIAT) to total assets [1], [2], [3].

The CRis the ratio used to measure the company's ability to meet term obligations in short which is due soon by using the total current assets available. It is a widely used measurement to evaluate company liquidity and ability to pay short-term debt. High CR shows that the better the company is in managing its current assets so that it can meet the company's ability to meet its obligations [4], [5], [6].

(C) 2020 The Author(s). This is an open access article distributed under the terms of the Creative Commons Attribution License, which permits unrestricted use, distribution, and reproduction in any medium, provided the original author and source are credited. 
The lower value of the CR indicates the company's inability to generate profits due to the limited it that can be used in the company's operations because most of it that will be used to meet short-term obligations, so this can affect the profitability of the company.

DER is a ratio used to calculate the extent to which owner's equity can cover debt to outside parties. It is a ratio that measures the extent to which a company is able to meet its long-term obligations. It is a comparison between funds originating from owners and funds originating from creditors. It is a ratio used to measure the ratio between total debt to total equity. Debt to equity ratio is a ratio that shows the ratio between debt and own capital [7], [8], [9].

High and low DER will affect the level of ROA achievement achieved by the company. If the costs incurred by the loan are smaller than the cost of capital alone, then the source of funds derived from loans or debt will be more effective in generating profits, and vice versa. Companies with growing profits will strengthen the relationship between DER and profitability, which is where its increases along with low it. The higher of DER, The more efficient a company is managing assets to generate profits.

TATO is a ratio that measures the extent to which a company's effectiveness in managing its assets in generating sales, or can also be said, to compare the acquisition of sales with assets owned. The choice of this ratio is because the effectiveness of the company in generating sales using its assets will be demonstrated through its calculations. The amount of its value will show assets that are faster in turning in generating sales to make a profit. Sales volume can be increased by the same amount of assets if the total asset turnover is enlarged or increased.

The company's sales activities by utilizing its total assets are reflected through it). The amount of assets used in the company's operations will affect the level of sales, then the level of sales will affect the amount of profit. So it can be concluded that TATO affects profitability where the higher of TATO the higher the ROA and vice versa.

The reason the authors conducted research at PT. Ira Widya Utama Medan because the authors found problems related to profitability that is not stable from year to year. So the authors are interested in conducting further research related to CR, DER, TATO to ROA in the last 10 years.

\section{MATERIALS AND METHODS}

\subsection{CURRENT RATIO (CR)}

It is the ratio commonly used to measure the ability of companies to meet short-term liabilities that will mature in one year. This ratio calculation aims to find out how far the actual amount of the company's current assets can guarantee debt from short-term creditors [10].

It is too high is also considered not good because of the many funds that are unemployed. High CR may indicate the existence of excessive cash compared to the level of need or the presence of elements of it that is low in liquidity (such as excess inventory) Vice versa, low CR means there is a liquidity problem. Low It is relatively riskier, but it shows that management has operated its CR effectively [11].

\subsection{DEBT TO EQUITY RATIO (DER)}

It ratio is a ratio used to calculate the extent to which owner's equity can cover debt to outside parties. Meanwhile. It is a ratio that measures the extent to which a company is able to meet its long-term obligations. It is a comparison between funds originating from owners and funds originating from creditors [12]

\subsection{TOTAL ASERT TURN OVER (TATO)}

It is a ratio that shows the effectiveness of companies in using overall assets to create sales and get profits. It is a ratio used to measure the effectiveness of the total assets of the company in generating sales [13].

\subsection{RETURN ON ASSERT (ROA)}

It involves elements of net income and TATO where net income is divided by total assets managerial or total assets of the company to make a good concept management system in multiplied by $100 \%$ forming it [13]. 


\section{RESULTS AND DISCUSSIONS}

This research uses causal design that analyzes the causal relationship among all varibales. The population and sample in this study is the financial statements owned by PT. Ira Widya Utama Medan, which is engaged in General Contractors and plantations through the balance sheet and income statement from 2008-2017.

The type of data used in this study is quantitative data, where quantitative data, which is data that is a collection of numbers resulting from observations. Data sources used in this study are secondary data obtained from various sources, in the form of financial reports obtained directly from PT. Ira Widya Utama Medan, consisting of balance sheet and income statement as the secondary data in the form of documentation and annual reports such as the balance sheet and income statement from 2008 to 2017. Before continuing the regression, The classical assumption is used to to see the feasibility of the model using Heteroscedasticity, Multicollinearity, Normality.

The Research Data Analysis Model is a multiple linear regression analysis used with the intention to determine the effect of the current ratio, debt to equity ratio, and total asset turnover on profitability, whether each variable is positively or negatively related the T-Test and F-Test as well as $\mathrm{R}^{2}$ using spss software with the pattern

$$
Y=a+b_{1} X_{1}+b_{2} X_{2}+b_{3} X_{3}+e
$$

It can be explained with :

Profitability $=\mathbf{a}+\mathbf{b} 1$ Current Ratio $+\mathbf{b} 2$ Debt to equity ratio $+\mathbf{b} 3$ Total Asset Turnover $+\mathbf{e}$

\section{RESULT AND DISCUSSION}

\subsection{RESULT}

This study informs how the influence of CR, DER and TATO on ROA. The object of the company used in this study is the annual financial statements for the period 2008-2017 at PT. Ira Widya Utama Medan is a company engaged in the field of general contractor and it is obtained directly from the manager in the financial department.

The descriptive statistical results before the transformation that the number of observations is 40 which is quarterly data for 10 years of financial statements for the period 2008-2017.

1) $\mathrm{CR}$

It has a minimum value of 0.29 , a maximum value of 3.66 with an average value (mean) of 1.5370 and a Standard Deviation of 0.76029 .

2) DER

It has a minimum value of 0.02 , a maximum value of 2.13 with an average value (mean) of 0.8368 and a Standard Deviation of 0.50455 .

3) TATO

It Turnover has a minimum value of 0,0003, a maximum value of 18.00 with an average value (mean) of 0.5891 and a Standard Deviation of 2.82912.

4) ROA

It has a minimum value of 0.18 , a maximum value of 15.44 with a mean value of 4.9580 and a standard deviation of 3.89994 .

By processing data using with SPSS V. 23 program, It can be concluded that the impact of using regression analysis, is to conclude whether the rise and fall of variables can be done through raising and decrease them,

The form of the equation of this multiple linear regression model is:

\section{Profitability = 13,123 - 6,051CR + 1,492DER + 7,344TATO + e}

The equation of the multiple linear regression model for ROA can transfered as follows:

1) In this regression model, a constant value of 13,123 (positive value) means that if the CR, DER and TATO the value is 0 , the Profitability ROA value is $13.23 \%$ 
Factors That Influence the Level of Profitability Managerial in Medan

2) CR regression coefficient value of $-6,051$ (negative value) in this study can be interpreted that ithas a significant negative effect on ROA. This shows that the increased CR has no impact on the ROA.

3) DER regression coefficient value of 1.492 (positive value) in this study can be interpreted that the DER variable has a positive but not significant effect on ROA. This shows that the better the company in fulfilling its obligations in a certain time with the ratio of equity owned for one year.

4) TATO regression coefficient value of 7,344 (positive value) in this study can be interpreted that it has a significant positive effect on ROA. This shows that how much the company is able to increase its sales in using assets to make a profit within a predetermined target within one year.

It shows that there is a significant correlation or relationship between the CR, DER and TATO as an independent variable and ROA as the dependent variable with the ROA analysis. This can be seen from the Adjusted $\mathrm{R}^{2}$ value obtained 0.680 which means $68.0 \%$ thus the variable current ratio, debt to equity ratio and total asset turnover simultaneously have a strong level so that they can provide an explanation on the variable ROA. And the remaining $32.0 \%$ is explained by other factors not included in this research model.

\subsection{DISCUSSION}

\subsubsection{EFFECT OF CR ON ROA IN PT. IRA WIDYA UTAMA MEDAN}

From the theory put forward by the experts above it can be concluded that CR is a ratio that compares current assets with it. It provides information about the ability of CR to cover current debts.

The theory put forward by the experts above is not in accordance with the phenomena that occur at PT. Ira Widya Utama Medan, where each year It owned by PT. Ira Widya Utama Medan has an average value of 1.05 times, which means the company has long-term debt and short-term debt which is quite large so that the obligation of the company to fulfill its obligations in covering or paying off these debts before maturity, from an agreement determined both from the creditors and the banks that lend funds as the idea [1], [2], [3], [10], [11].

Although PT.Ira Widya Utama Medan has a low profitability (ROA) due to the assets owned by the company began to decrease after the change of owner, the PT. Ira Widya Utama Medan took the initiative to merge with other companies to obtain additional funds as initial capital and to be able to pay off these debts before maturity, so that the capital turnover from the loan funds was rotated to renovate property owned by PT. Ira Widya Utama Medan and also to add company assets by buying new construction equipment and also expanding such as oil palm, sugar cane, and other plants that also provide benefits or profits for the company to survive in the face of economic globalization that is in Indonesia one of which is the decline in the rupiah in recent years.

The results of the study are not in accordance with the theory put forward by experts and previous researchers, where research on the effect of current ratio on profitability (ROA). Partially CR has a significant negative effect on ROA and the authors conclude that the company's lack of ability to cover long-term debt obligations and short-term debt to increase the return on assets owned by PT. Ira Widya Utama Medan.

\subsubsection{EFFECT OF DER ON ROA IN PT. IRA WIDYA UTAMA MEDAN}

From the theory put forward by the experts above it can be concluded that the DER is a financial ratio that shows the relative proportion between Equity and Debt used to finance company assets. High and low DER will affect the level of ROA achievement achieved by the company. If the costs incurred by the loan are smaller than the cost of capital alone, then the source of funds derived from loans or debt will be more effective in generating profits.

The theory put forward by the experts above is not in accordance with the phenomena that occur at PT. Ira Widya Utama Medan, DER is a ratio that shows the ratio between total liabilities and total equity in equity funding. PT. Ira Widya Utama Medan has a high DER so that the profits generated by the company are getting lower, this shows the proportion of capital owned is smaller than the company's liabilities or high dependency from outside parties. PT. Ira Widya Utama Medan has too many obligations so that it is difficult to get additional funds from outside parties, therefore the company is innovating and improving its assets in order to be able to increase investor interest in investing in PT. Ira Widya Utama Medan as the idea [4], [5], [6], [12]. 
In general, debt carries a risk because every debt, will cause a permanent relationship for the company, in the form of an obligation to pay interest expenses and installments periodically. therefore the company must be able to use the debt effectively and asfully as possible because it will be able to provide benefits to the company. This can be related to the amount of debt to equity ratio, because the lower the ratio is a profitable signal for investors because it can prove that if the company in obtaining its funding utilizes more capital than debt.

The results of this study are not in accordance with the theory put forward by experts and previous researchers, where research on the effect of DER on profitability (ROA). Partially the DER has no significant positive effect on ROA. The authors conclude that the smaller the debt to equity ratio and the company's debt and the greater the equity owned will attract investors to invest their shares, because this is wrong. one factor is the right decision in investment and the use and use of it to generate profits for PT. Ira Widya Utama Medan.

\subsubsection{EFFECT OF TATO ON ROA AT PT. IRA WIDYA UTAMA MEDAN}

From the theory put forward by the experts above it can be concluded that TATO is a ratio that measures the extent to which the effectiveness of the company in managing its assets in generating sales, the amount of TATO value will show assets that are faster in turning in generating sales for profit. Sales volume can be increased by the same amount of assets if the total asset turnover is enlarged or increased.

The theory put forward by the experts above is in accordance with the phenomena that occur at PT. Ira Widya Utama Medan, total asset turnover is part of one activity ratio that shows how effectively the company uses its assets to create revenue from sales, where the company's ability to use total asset turnover in managing all assets owned if the company's effectiveness uses assets To obtain a high level of sales, it is expected that the company's profitability will increase, thereby increasing profit growth significantly.

PT. Ira Widya Utama Medan is able to manage all its assets well so as to increase sales results in the last 5 years the company is able to optimize the total assets owned. At this time PT. Ira Widya Utama Medan again tried to maximize the total assets owned to increase the profitability of the company by purchasing several assets that were important to the company such as dozers, trucks (pickups), computer units, cars and also sugarcane and corn grinding machines. This was done to facilitate the company in managing plantations such as oil palm, sugar cane, corn and several other plants.

The results of the study are in accordance with the theory put forward by experts and previous researchers, where research on the effect of total asset turnover on profitability (ROA). As partially, It has a significant positive effect on ROA the authors conclude that the company's ability to manage all assets owned to increase sales of production, in order to achieve the predetermined target of obtaining the highest possible profit as the idea [7], [8], [9], [13].

\subsubsection{EFFECT OF CR, DER AND TATO ON ROA IN PT. IRA WIDYA UTAMA MEDAN}

It has conducted research on the effect of the level of liquidity, solvency, activity on profitability in manufacturing companies listed on the Indonesian Exchange that the current ratio, debt to equity ratio and total asset turnover together affect positive and significant towards profitability as the idea [13].

\section{CONCLUSIONS AND RECOMMENDATIONS}

\subsection{CONCLUSION}

This study examines whether CR, DER and TATO has an influence on profitability using Return On Assets (ROA) at PT. Ira Widya Utama Medan from the annual financial statement data in the form that can be drawn, such as :

1) From the results of simultaneous regression testing, there is a significant positive effect between the variable CR, DER and TATO on the variable ROA PT. Ira Widya Utama Medan.

2) CR test results partially have a significant negative effect on ROA at PT. Ira Widya Utama Medan

3) DER has partially an insignificant positive effect on ROA at PT. Ira Widya Utama Medan.

4) TATO has partially a significant positive effect on ROA at PT. Ira Widya Utama Medan. 
Factors That Influence the Level of Profitability Managerial in Medan

\subsection{RECOMMENDATION}

Based on the results of this study, researchers tried to provide good advice and input for the company PT. Ira Widya Utama Medan and could be a reference for further researchers.

1) Increase the company's activities so that the assets owned by the company can spin faster than in previous years and not more than 1 year. It is recommended that assets owned by the company can be more productive so as to increase company sales.

2) Maintaining the company's solvency position in the amount of debt owned by the company is not too large and also maintaining that the company's working capital continues to increase and increase profits received by the company so that the capital owned by the company can guarantee the company's debt.

3) It is better for PT. Ira Widya Utama Medan to sell the company's shares or merge with other companies in order to increase capital for management funds as well as the company's needs in order to increase revenue and in the future be able to increase the company's profitability better.

4) For further research, it is expected to increase the variables contained in the liquidity, solvency and activities that can affect the profitability of the company, as well as increase the number of samples and increase the research period so that the results of the data obtained are more accurate and valid.

\section{SOURCES OF FUNDING}

This research received no specific grant from any funding agency in the public, commercial, or not-for-profit sectors.

\section{CONFLICT OF INTEREST}

The author have declared that no competing interests exist.

\section{ACKNOWLEDGMENT}

The authors give the special appreciation for the chief of research Universitas Al Azhar, Medan, Sumatera Utara.

\section{REFERENCES}

[1] Brigham, Eugene F. dan Joel F. Houston,. 2012. Dasar-Dasar Manajemen Keuangan Edisi V. Jakarta: Salemba Empat, 2012.

[2] Fahmi, Irham. 2012. Analisis Kinerja Keuangan. Bandung: Alfabeta, 2012.

[3] Hanafi, Mamduh M. dan A. Halim. 2007. Analisis Laporan Keuangan, Edisi 3.. Yogyakarta: Penerbit UPP STIM YKPN., 2007.

[4] Hanafi, Mamduh M. 2010. Manajemen Keuangan Edisi Pertama. Yogyakarta: BPFE, 2010.

[5] Harahap, Sofyan Syafri. 2011. Analisis Kritis atas Laporan Keuangan. Jakarta: PT Raja Grafindo Persada, 2011.

[6] Hery. 2016. Analisis Laporan Keuangan, Edisi 1. Yogyakarta: Centre For Academic Publishing Services, 2016.

[7] Husnan, Suad dan Enny Pudjiastuti. 2004. Dasar-Dasar Manajemen Keuangan Edisi Keempat. Yogyakarta: UPP AMP YKPN, 2004.

[8] Jumingan. 2014. Analisa Laporan Keuangan Cetakan Keempat . Jakarta: Media Grafika, 2014.

[9] Kasmir. 2014. Analisis Laporan Keuangan, Edisi Pertama, Cetakan Ketujuh.. Jakarta: PT Raja Grafindo Persada, 2014.

[10] Kieso, Donakd E., Jerry J. Weygandt, dan Terry D. Warfield. 2013. Akuntansi Intermediate, Edisi 15. Jakarta: Erlangga, 2013.

[11] Margaretha, Farah. 2011. Manajemen Keuangan untuk Manajer Non Keuangan. Jakarta: Salemba Empat, 2011.

[12] Murhadi, R. Werner,. 2013. Analisis Laporan Keuangan Proyeksi dan Valuasi Saham. Jakarta: Salemba Empat, 2013.

[13] Tjiptono, Darmaji and Fakhruddin, Hendi M. 2012. Pasar Modal Indonesia Pendekatan Tanya Jawab. Edisi Empat,. Jakarta: Salemba Empat., 2012. 